\title{
IDENTIFIKASI JENAZAH YANG DITEMUKAN DI PINGGIR PANTAI
}

\author{
Taufik Suryadi $^{1 *}$, Muhammad Jundi Ramadhanif ${ }^{2 *}$, Rona Puspa Sari ${ }^{2 *}$, Ayu \\ Wulandari $^{2 *}$, Farah Kamila ${ }^{2 *}$ \\ ${ }^{1}$ Department of Forensic Medicine and Medico-legal, Faculty of Medicine, \\ Universitas Syiah Kuala, Banda Aceh, Indonesia \\ *Email : taufiksuryadi@unsyiah.ac.id \\ ${ }^{2}$ Medical Student of Forensic Medicine Clinical Rotation, \\ Faculty of Medicine, Universitas Syiah Kuala, Banda Aceh, Indonesia \\ *Email :m.jundi0922@gmail.com, ronapuspasari@gmail.com, \\ ayu98.aw@gmail.com, farkamila25@gmail.com
}

\begin{abstract}
ABSTRAK
Identifikasi merupakan suatu upaya membantu penyidik dalam menentukan identitas serta sebab kematian seseorang. Pada beberapa kasus pemeriksaan identifikasi jenazah dilakukan pada jenazah yang sudah dikuburkan, sehingga pemeriksaan forensik setelah ekshumasi menjadi cara terakhir untuk mendapatkan data terkait identitas dan penyebab kematian korban. Pada artikel ini dilaporkan proses identifikasi sesosok jenazah tanpa identitas dengan anggota tubuh yang tidak lengkap yang ditemukan oleh nelayan di pinggir pantai Pulo Aceh, Propinsi Aceh dalam keadaan telungkup di bawah boat. Jenazah sudah dikuburkan oleh warga, namun setelah terdapat informasi bahwa jenazah kemungkinan warga negara asing, penyidik melakukan prosedur ekshumasi pada jenazah tersebut untuk dilakukan identifikasi. Pada pemeriksaan luar ditemukan jenazah tidak utuh, tanpa kepala, berjenis kelamin laki-laki dengan perkiraan tinggi badan berdasarkan dengan panjang tulang humerus dan radius adalah sekitar 150,83-159,15 cm dan perkiraan tinggi badan menurut panjang tulang femur dan tibia adalah sekitar 151,32 - 157,79 cm, usia korban tidak dapat ditentukan. Untuk mendukung proses identifikasi dikirimkan sampel tulang radius dan ulna kiri guna pemeriksaan DNA. Penyebab kematian korban tidak dapat ditentukan karena sudah terjadi adiposera dan perkiraan waktu kematian korban lebih dari satu bulan.
\end{abstract}

Kata kunci: Identifikasi, Adiposera, Ekshumasi

\begin{abstract}
Identification is a part of investigation which assists investigators in identifying the identity and cause of death. In some cases, this investigation process is carried out for human remains from their place of interment which is known as exhumation. Exhumation usually acts as the last method in obtaining data about identity and other crucial informations of the victims. This article reported an identifying process of an unidentified human remains with incomplete limbs found by a fishermen under a boat on the coast of Pulo Aceh, Aceh Province. The bodies had been buried by residents until an information about probability of foreign citizenship was reported to investigators. Hence, investigators carried out an exhumation procedure on the bodies for identification. Physical examination showed that the body was incomplete and headless. It was assumed that the body belonged to a male with an estimated height was around $150.83-159.15 \mathrm{~cm}$ based on the length of the humerus and radius, and was approximately $151.32-157.79 \mathrm{~cm}$ by using the length of the femur. The age of the victim could not be determined. To support the identification process, samples of the left radius and ulna were sent for DNA examination. The cause of death of the victim could not be determined because of the formation of adipocere. It is estimated that the victim had been died for more than one month.
\end{abstract}

Keywords: Identification, Adipocera, Exhumation 


\section{PENDAHULUAN}

Dalam dunia kedokteran forensik terdapat istilah proses identifikasi. Proses identifikasi dapat dilakukan pada orang hidup ataupun jenazah. Identifikasi pada jenazah sering dilakukan pada kasus jenazah yang tidak memiliki identitas, jenazah yang sudah membusuk, jenazah pada bencana alam, jenazah pada kasus kebakaran dan penemuan jenazah dengan bagian tubuh yang tidak lengkap [1].

$$
\text { Pada beberapa kasus }
$$

pemeriksaan identifikasi jenazah harus dilakukan pada jenazah yang sudah dikuburkan, sehingga pemeriksaan forensik setelah ekshumasi menjadi pilihan utama dan menjadi cara terakhir untuk mendapatkan identifikasi forensic [2].

Ekshumasi atau penggalian jenazah adalah prosedur penggalian kuburan untuk mengeluarkan jenazah agar dapat dilakukan pemeriksaan yang sesuai aturan hukum. Ekshumasi dapat dilakukan untuk berbagai kepentingan, seperti kepentingan penyidikan karena adanya kecurigaan tindak pidana. Ekshumasi dilakukan karena setelah dikuburkan terdapat kecurigaan pada beberapa hal seperti penyebab kematian yang tidak wajar, adanya dugaan yang salah saat pemeriksaan sebelumnya, dan kecurigaan terhadap identitas mayat tersebut [2].

Pemeriksaan forensik pada ekshumasi menjadi cara terakhir untuk mendapatkan diagnosis forensik pada kasus yang tidak diketahui sebagai suatu tindak pidana atau kasus yang tidak terolah dengan benar sebelumnya, baik kasus yang terjadi karena kecelakaan, kekerasan, pembunuhan maupun kasus lainnya seperti tenggelam.[2] Pada kasus ini dilakukan pemeriksaan forensik pasca ekshumasi pada jenazah tanpa identitas yang tertelungkup di bawah sebuah boat yang ditemukan di pinggir pantai.

Tahapan utama dalam penentuan sebab kematian pada kasus jenazah yang ditemukan di pinggir perairan adalah mencari tahu apakah kematian itu disebabkan oleh tenggelam dalam air atau oleh sebab lain. Temuan pemeriksaan autopsi (pemeriksaan internal dan eksternal secara rinci serta pemeriksaan laboratorium) dan temuan pada investigasi Tempat kejadian perkara (TKP) serta kondisi setelah kematian dan proses ekstraksi dari air dapat membantu dalam menunjukkan sebab kematian jenazah tersebut [3]

Pada artikel ini dipaparkan lebih lanjut mengenai identifikasi serta pemeriksaan forensik pada sebuah kasus ekshumasi mayat tanpa identitas yang ditemukan di pinggir pantai.

\section{LAPORAN KASUS}

Telah ditemukan sesosok jenazah tanpa identitas dengan anggota tubuh yang tidak lengkap oleh nelayan di pinggir pantai Pulo Aceh, Provinsi Aceh dalam keadaan telungkup di bawah sebuah boat. Jenazah sudah sempat dikuburkan oleh warga setempat selama beberapa jam, kemudian pihak kepolisian melakukan ekshumasi pada jenazah tersebut untuk dilakukan identifikasi. Berdasarkan laporan TKP, nomor boat yang ditemukan di sekitar jenazah berkode negara Sri Lanka, sehingga diduga korban adalah warga negara asing. 
Pemeriksaan yang dilakukan pada jenazah tersebut berupa pemeriksaan luar dan pemeriksaan lanjutan berupa identifikasi Deoxyribo Nucleic Acid (DNA) dari kerangka tulang. Pada pemeriksaan luar ditemukan jenazah dibungkus dalam kantong jenazah berwarna hitam bertuliskan BASARNAS dengan ukuran $192,5 \mathrm{~cm}$ x $84 \mathrm{~cm}$. Jenazah ditutup kain kafan bewarna putih dengan ukuran $136,5 \mathrm{~cm} \times 41$ $\mathrm{cm}$ dan setelah dibuka panjang penutup adalah $154,5 \mathrm{~cm}$ x $150,6 \mathrm{~cm}$.

Bagian tubuh yang ditemukan pada jenazah tersebut adalah thorax, abdomen, regio brachii dextra, regio brachii sinistra, tulang radius dan ulna sinistra, regio femoralis dextra, regio femoralis sinistra, tulang tibia dextra, dan tampak sebagian costae pada punggung belakang seperti pada Gambar 1 dan Gambar 2. Paru-paru pada korban juga sudah mengering sehingga tidak bisa ditentukan apakah terdapat cairan atau tidak dalam paruparu.

Bagian tubuh yang tidak ditemukan pada jenazah tersebut adalah kepala, tulang radius dan ulna dextra, dan tulang tibia sinistra, serta tidak ditemukan regio manus dan pedis.

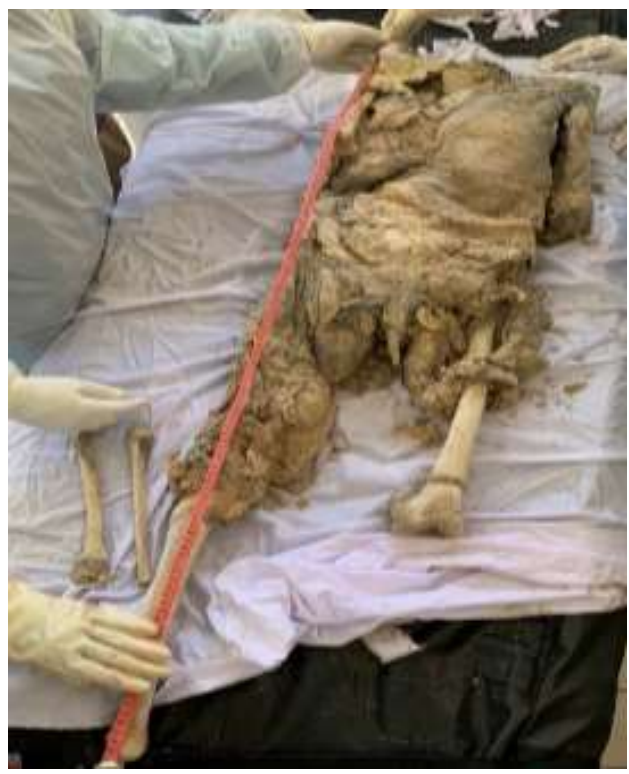

Gambar 1. Bagian tubuh yang ditemukan pada jenazah

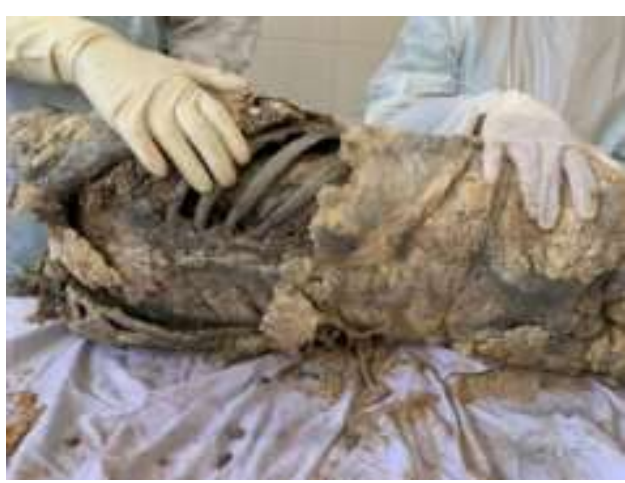

Gambar 2. Bagian belakang tubuh pada jenazah

Lebam mayat dijumpai pada dada, perut, paha kiri dan kanan. Tidak ditemukan penurunan suhu dan tidak ditemukan adanya kaku mayat karena sudah terjadi adiposera dan proses pembusukan sudah selesai. Kulit tampak keras dan menguning akibat proses adiposera. Alat kelamin berupa alat kelamin laki-laki yang sudah hancur dan tampak rambut kemaluan seperti pada Gambar 3. Dubur hancur dan tidak dapat diidentifikasi akibat adiposera. Perut 
dan pinggang juga sudah mengalami adiposera.

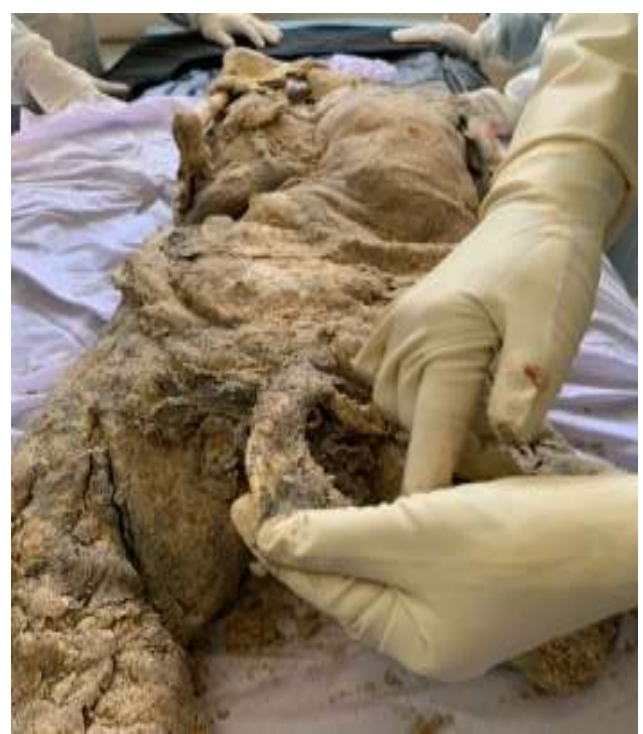

Gambar 3. Alat kelamin jenazah

Pada pengukuran tubuh, ditemukan lebar bahu $30 \mathrm{~cm}$, lebar dada $35 \mathrm{~cm}$. Pada pengukuran ekstremitas atas ditemukan panjang tulang humerus dextra $24 \mathrm{~cm}$, panjang tulang humerus sinistra $24 \mathrm{~cm}$, panjang tulang radius sinistra $24 \mathrm{~cm}$ dan panjang tulang ulna sinistra 23,5 $\mathrm{cm}$. Pada pengukuran ekstremitas bawah ditemukan bahwa panjang tulang femur dextra $36 \mathrm{~cm}$, tulang femur sinistra $36 \mathrm{~cm}$ dan tulang tibia dextra $33 \mathrm{~cm}$.

Berdasarkan formula M. Trotter dan G.C Glesser diperoleh perkiraan tinggi badan sebagai berikut:

Perkiraan tinggi badan dengan panjang tulang humerus dan radius: $=$

1,67(humerus+radius) $+74,83( \pm 4,16 \mathrm{~cm})$

$=1,67(24+24)+74,83( \pm 4,16 \mathrm{~cm})$

$=80,16+74,83( \pm 4,16 \mathrm{~cm})$

$=154,99( \pm 4,16 \mathrm{~cm})$

$=150,83-159,15 \mathrm{~cm}$

Perkiraan tinggi badan dengan panjang tulang femur dan tibia:

$$
\begin{aligned}
& =1,22(\text { femur+tibia })+70,37( \pm 3,24 \mathrm{~cm}) \\
& =1,22(36+33)+70,37( \pm 3,24 \mathrm{~cm}) \\
& =84,18+70,37( \pm 3,24 \mathrm{~cm}) \\
& =151,32-157,79 \mathrm{~cm}
\end{aligned}
$$

Pada jenazah ini tidak dilakukan pemeriksaan dalam karena tidak adanya permintaan dari penyidik untuk dilakukan otopsi. Pemeriksaan lanjutan yang dilakukan berupa pemeriksaan identifikasi kerangka tulang berupa tulang radius dan ulna.

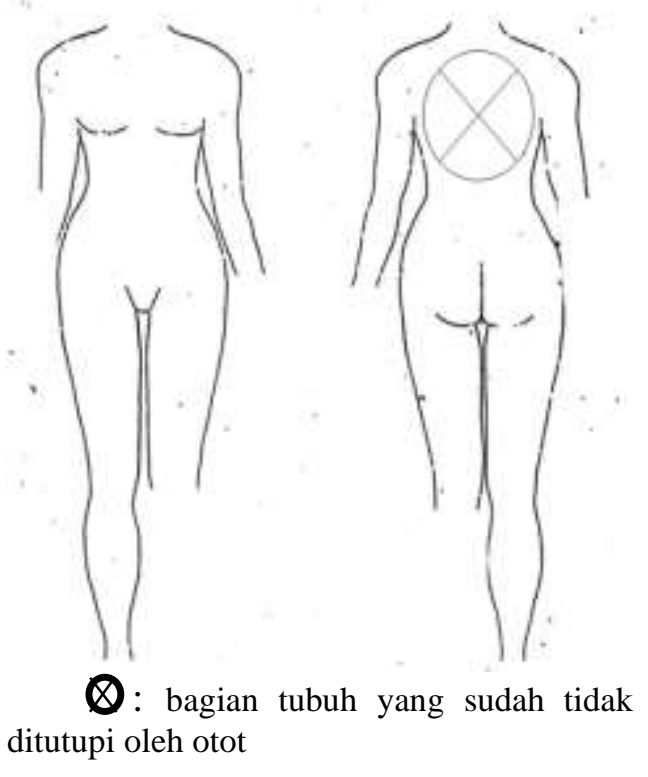

Gambar 4. Bagian tubuh jenazah

\section{DISKUSI}

Identifikasi jenazah menjadi hal yang penting dalam kedokteran forensik karena dapat mempermudah penyidik dalam menentukan identitas pada jenazah yang tidak dikenali. Pada pembuatan visumet repertum, jenazah tersebut dikenal sebagai Mr.X. Pemeriksaan ini menjadi sulit ketika jenazah ditemukan dalam kondisi telah mengalami pembusukan atau hanya tinggal tulang [1].

Pemeriksaan yang dilakukan pada proses identifikasi orang hidup berupa pemeriksaan fisik, 
pemeriksaan golongan darah, pemeriksaan ciri-ciri tubuh tertentu, pemeriksaan sidik jari, pemeriksaan fotografi dan pemeriksaan benda milik pribadi. Sedangkan pemeriksaan yang dapat dilakukan pada jenazah adalah pemeriksaan luar dan pemeriksaan dalam [4].

Pada pemeriksaan luar pada kasus ini didapatkan jenazah dibawa dengan kantong jenazah berwarna hitam bertuliskan BASARNAS. Penutup jenazah yaitu kain kafan berwarna putih, yang sebelumnya jenazah telah dilakukan ekshumasi dengan organ yang tidak lengkap. Bagian tubuh yang ditemukan pada jenazah tersebut adalah thorax, abdominal, regio brachii dextra, regio brachii sinistra, tulang radius dan ulna sinistra, regio femoralis dextra, regio femoralis sinistra, tulang tibia dextra, dan tampak sebagian costae pada punggung belakang. Bagian tubuh yang tidak ditemukan pada jenazah tersebut adalah kepala, tulang radius dan ulna dextra, dan tulang tibia sinistra, serta tidak ditemukan regio manus dan pedis.

Pemeriksaan

kedokteran

forensik pada kasus ekshumasi atau penggalian jenazah dapat dilakukan karena berbagai kepentingan, seperti kepentingan penegakan hukum. Namun pemeriksaan ekshumasi perlu mempertimbangkan pertanyaan yang perlu dijawab dalam suatu penyidikan, dan apakah pertanyaan tersebut dapat dijawab melalui pemeriksaan forensik setelah proses ekshumasi [2].

Korban tenggelam dalam air dapat diidentifikasi melalui pembentukan busa putih seperti jamur di sekitar mulut dan hidung, yang menunjukkan bahwa orang yang terendam hidup-hidup di dalam air selama proses pernapasan aktif sehingga terjadi aspirasi cairan. Selain itu, aspirasi cairan dapat memberikan gambaran pembesaran paru-paru yang ekstrim, paru hiperemis, dan ditemukan pelebaran alveolar. Perdarahan di konjungtiva juga merupakan karakteristik kematian akibat asfiksia. Kematian akibat tenggelam terkadang sulit ditegakkan apabila tidak ditemukan tanda yang khas baik dari pemeriksaan luar dan dalam.[3] Pada kasus ini, kepala korban tidak ditemukan dan paru-paru korban sudah mengering, sehingga penyebab kematian sulit ditentukan.

Tanda-tanda pasti kematian pada jenazah seperti livor mortis (lebam mayat), rigor mortis (kaku mayat) dan dekomposisi dapat digunakan untuk menentukan perkiraan waktu kematian (post mortem interval).[5] Tanda-tanda kematian pada kasus ini dijumpai adanya lebam mayat di dada, perut dan paha kiri dan kanan. Pada mayat yang telah mengalami pembusukan, lebam mayat sulit dibedakan dengan resapan darah. Namun, lebam mayat dapat terjadi sepanjang waktu sebelum terjadi proses penghancuran jaringan tubuh. Karena pada mayat yang telah membusuk, sel darah merah mengalami proses lisis, endotel pembuluh darah juga mengalami kerusakan karena proses pembusukan sehingga sel darah merah keluar dari pembuluh darah. Untuk membedakannya dengan memar perlu dilakukan pemeriksaan histopatologi forensik, namun pada kasus ini tidak dilakukan pemeriksaan histopatologi. Apabila dilakukan pemeriksaan histopatologi 
diharapkan jika lebam mayat maka eritrosit tampak menumpuk di sekitar pembuluh darah, berbatas tegas, tidak tampak adanya reaksi jaringan, sel Polimorfonuklear (PMN) dan sel radang lainnya tidak ditemukan. Sedangkan jika memar eritrosit tampak difus dijaringan dan tampak adanya reaksi jaringan yaitu tampak adanya sel-sel radang [1].

Kaku mayat tidak ditemukan pada jenazah ini karena sudah terjadi proses adiposera dengan tampak kulit berwarna kekuningan dan mengeras. Adiposera terbentuk ketika tubuh sudah dalam keadaan lembab di air. Perubahan ini terjadi karena proses hidrogenasi dalam lemak bebas, seperti asam aleat yang dirubah menjadi asam lemak jenuh. Kemudian seluruh lemak dirubah menjadi asam palmitat, stearat, asam hidroksi stearat dan campuran seluruh bahan tersebut menjadi suatu substansi asam lemak yang lunak, putih kecokelatan, berminyak dan bau yang khas sehingga disebut adiposera [1].

Adiposera biasanya terjadi pada jenazah yang berada di daerah tropis dan mulai terjadi setelah 1-3 minggu. Pada orang dewasa, adiposera mulai terjadi secara keseluruhan dalam waktu 3-6 bulan bahkan sampai 12 bulan tergantung lokasi, suhu sekitar kelembaban lingkungan [1].

Kepala dan wajah sudah tidak ditemukan pada jenazah ini. Kepala jenazah yang berada di dalam air akan berada dalam posisi terendah karena lebih berat dibandingkan bagian tubuh lainnya yang menyebabkan proses pembusukan lebih cepat terjadi pada bagian kepala [1].

Alat kelamin berupa alat kelamin laki-laki yang sudah hancur dan tampak rambut kemaluan ditemukan pada jenazah ini. Penentuan jenis kelamin pada korban yang memiliki alat kelamin yang masih utuh biasanya mudah dilakukan dengan hanya melihat genitalia eksterna dan tanda-tanda perubahan seks sekunder, seperti pertumbuhan payudara, jakun, pertumbuhan rambut pubis dan tandatanda lainnya. Pada korban yang tidak utuh dan sudah mengalami pembusukan, jenis kelamin dapat dinilai dari keadaan tulang, otot, kulit, rambut kepala, rambut pada kulit dan linea albicans. Pada jenazah ini ditemukan adanya alat kelamin lakilaki berupa penis yang sudah hancur dengan rambut kemaluan [1]. Pada kasus ini penentuan jenis kelamin tidak dikonfirmasi dengan pemeriksaan DNA.

Identifikasi jenazah tanpa identitas dapat dilakukan dengan identifikasi antropologi pada bagianbagian tulang jenazah. Identifikasi tulang tidak hanya dilakukan pada tulang saja, namun juga dapat dilakukan pada tulang saat masih dilapisi oleh otot, tendon dan kulit. Hal yang dapat diperoleh pada saat pemeriksaan identifikasi tulang adalah jenis kelamin, ras, tinggi badan, dan perkiraan usia korban juga dapat dilakukan dengan melihat gambaran epifisis.[6] Tanda-tanda degradasi tulang jangka panjang dapat dilihat dari perubahan warna, dan tampak adanya keretakan yang berbentuk transversal dan longitudinal pada permukaan tulang [7].

Usia jenazah pada kasus ini sulit ditentukan karena tidak adanya bagian yang dapat diidentifikasi seperti kepala dan gigi. Penentuan 
usia pada jenazah dapat dilakukan berdasarkan pertumbuhan gigi, pertumbuhan kerangka atau perubahan degeneratif kerangka. Pada orang dewasa, usia dapat diperkirakan dengan memperhatikan proses resorpsi, deposisi dan remodeling tulang. secara antropologi forensik, penentuan usia pada orang dewasa dilakukan dengan pemeriksaan simfisis pubis, ujung iga sternum, permukaan aurikular tulang ilium dan sutura kranial. Sedangkan pemeriksaan usia pada orang dewasa secara konvensional biasanya berupa pemeriksaan klavikula, permukaan acetabular dan femur proksimal [8]. Pada kasus ini tidak dapat dilakukan pemeriksaan usia berdasarkan gambaran tulang femur dan ilium karena gambaran trabekulasi tulang tersebut sulit diidentifikasikan.

Penentuan usia berdasarkan pertumbuhan, jumlah dan urutan gigi sangat penting terutama pada usia anak-anak dan remaja. Pemeriksaan radiografi gigi untuk melihat proses mineralisasi gigi juga lebih akurat dibandingkan mineralisasi tulang pada penentuan usia [9].

Perkiraan usia berdasarkan ujung sternum iga menurut McCornick dan Stewart dengan melihat perubahan lempeng dada dan gambaran osifikasi yang khas. Kartilago costae di ujung sternum secara sentrikondral dan peristernal dapat menggambarkan perkiraan usia korban [8].

Pada kasus ini, pengukuran tulang ditemukan lebar bahu $30 \mathrm{~cm}$, lebar thorax $35 \mathrm{~cm}$. Pada pengukuran ekstremitas atas ditemukan panjang tulang humerus dextra $30 \mathrm{~cm}$, panjang tulang humerus sinistra $30 \mathrm{~cm}$, panjang tulang radius sinistra $24 \mathrm{~cm}$ dan panjang tulang ulna sinistra 23,5 $\mathrm{cm}$. Pada pengukuran ekstremitas bawah ditemukan bahwa panjang tulang femur dextra $36 \mathrm{~cm}$, tulang femur sinistra $36 \mathrm{~cm}$ dan tulang tibia dextra $33 \mathrm{~cm}$.

Perbedaan jenis kelamin berdasarkan bentuk tulang mulai terlihat jelas setelah masa pubertas. Perempuan memiliki tulang yang lebih kecil, lebih ringan, dan lebih halus hal ini dikarenakan perempuan memiliki origo dan insertio yang kurang menonjol. Tulang costae wanita juga lebih tipis dan lebih melengkung. Bentuk thorax perempuan lebih pendek dan lebar sedangkan thorax laki-laki lebih panjang dan sempit [1].

Pembagian ras dapat dibedakan menjadi ras Eropa, Mongol, dan Negro. Penentuan ras berdasarkan cephalic index dapat ditentukan dengan membagi lebar kepala terhadap panjang kepala. Berdasarkan indeks cephalic, terdapat 3 jenis bentuk kepala, yaitu dolichocephalic, mesocephalic, dan brachycephalic. Ras Negro memiliki bentuk kepala dolichocephalic dengan indeks cephalicus <75, dimana kepala berbentuk panjang dan sempit disertai dengan apertura nasal yang lebar. Ras Eropa memiliki karakteristik bentuk kepala mesocephalic dengan indeks cephalicus 75-80 dan dolichocephalic diikuti dengan tonjolan dahi yang besar serta hidung yang mancung. Sedangkan ras mongoloid memiliki bentuk kepala brachycephalic dengan indeks cephalicus > 80 yang ditandai dengan zygoma yang menonjol, apertura nasal yang sempit dan tonjolan dahi yang kecil. Pada kasus ini tidak dapat dilakukan penentuan 
ras berdasarkan cephalic index karena tidak ditemukan kepala korban [4].

Terdapat banyak metode yang dapat digunakan dalam memperkirakan tinggi badan seseorang. ${ }^{6}$ Tinggi badan dapat dilakukan tanpa perlu mengukur badan secara keseluruhan. Penentuan tinggi badan secara kasar dapat ditentukan dengan mengukur [1].

a. Rentangan tangan mulai ujung jari tengah tangan kiri sampai ujung jari tengah tangan kanan sama dengan tinggi badan. Pengukuran ini diperlukan apabila ditemukan jenazah mutilasi kepala.

b. Panjang lengan dikali 2 lalu ditambah $34 \mathrm{~cm}$ sama dengan 2 kali panjang klavikula ditambah 4 $\mathrm{cm}$ (lebar sternum).

c. Panjang puncak kepala (vertex) sampai simfisis pubis dikali 2 . Pengukuran ini diperlukan apabila ditemukan jenazah mutilasi anggota gerak bawah.

d. Panjang sternal notch sampai simfisis pubis dikali 3,3.

e. Panjang ujung jari tengah sampai ujung olecranon dikali 3,7 .

f. Panjang femur dikali 4 .

g. Panjang humerus dikali 6

Hasil pengukuran tersebut harus ditambahkan 2-4 cm sebagai tambahan jarak antar sendi [1].

Selain cara tersebut, terdapat rumus pengukuran tinggi badan yang lebih akurat dengan menggunakan rumus Trotter dan Glesser. [1] Menurut M. Trotter dan G.C Glesser, perkiraan tinggi badan jenazah berdasarkan dengan panjang tulang humerus dan radius sekitar 150,83$159,15 \mathrm{~cm}$. Sedangkan perkiraan tinggi badan berdasarkan panjang tulang femur dan tibia adalah sekitar $151,32-157,79 \mathrm{~cm}$.
Ada beberapa rumus lain yang dapat digunakan untuk menentukan tinggi badan, yaitu: rumus Karl peason, rumus Trotter dan Glesser, rumus Dupertuis dan Hadden, Regression Formula, Rumus Antropologi Ragawi Universitas Gadjah Mada untuk pria dewasa, dan rumus untuk populasi dewasa muda di Indonesia menurut Djaja Surya Atmadja. Sebelum menggunakan rumus tersebut, diperlukan pengukuran panjang maksimum dari tulang humerus, radius, ulna, femur, tibia dan fibula[4].

Pada kasus ini, pemeriksaan lanjutan untuk mencari tahu identitas korban yaitu dengan dilakukan pemeriksaan DNA tulang dengan mengirimkan sampel tulang radius dan ulna kiri. Sampel diserahkan kepada penyidik untuk dikirimkan ke laboratorium DNA forensik, sampai artikel ini ditulis belum ada laporan hasil pemeriksaan DNA tersebut.

Pelacakan identitas dapat dilakukan dengan mencocokkan antara DNA korban dengan keluarga korban.Kesulitan pada kasus ini mencari pembanding hasil DNA nantinya karena tidak ada sampel dari kedua orang tua dari kemungkinan jenazah yang diperiksa. Beruntung apabila jenazah mempunyai profil DNA sehingga memudahkan pelacakan identitas korban. Sampel yang paling sering digunakan untuk identifikasi DNA adalah darah, rambut, buccal swab dan kuku. Selain itu, identifikasi DNA dapat juga menggunakan sampel sperma, daging, tulang, kulit, dan air liur yang ditemukan di tempat kejadian [10].

Pemeriksaan DNA merupakan sumber utama yang dapat membantu untuk menetapkan identitas individu 
pada kasus jenazah tanpa identitas dan pada jenazah yang sudah mengalami pembusukan. Pemeriksaan pada gigi geligi atau tulang dapat membantu untuk mendapatkan profil DNA. Gigi adalah sumber terbaik untuk mengidentifikasi jenazah berdasarkan profil DNA gigi tersebut.Pada kasus jenazah yang terlambat diperiksa, profil DNA menggunakan apusan darah sering menimbulkan hasil negatif. Hal ini dikarenakan suhu cenderung menurunkan kualitas DNA meskipun diawetkan pada suhu $0^{\circ} \mathrm{C}$ [11].

\section{KESIMPULAN}

Pemeriksaan kedokteran forensik untuk tujuan identifikasi korban sangat penting dilakukan. Dalam pemeriksaan jenazah tidak dikenal, identifikasi penting yang dapat ditemukan adalah Sex, Age, Race dan Stature (SARS). Pada kasus ini telah ditetapkan hasil identifikasi jenazah yang diduga warga negara Sri Lanka yaitu sesosok jenazah laki-laki (sex), usia belum dapat ditentukan (age), ras diduga mongoloid yang ditentukan dari struktur tulang (race), sedangkan stature ditentukan dengan perkiraan tinggi badan menurut $\mathrm{M}$. Trotter dan G.C Glesser berdasarkan panjang tulang humerus dan radius sekitar 150,83-159,15cm, sedangkan perkiraan tinggi badan dengan menggunakan panjang tulang femur dan tibia adalah sekitar 151,32 $157,79 \mathrm{~cm}$. dari kombinasi pengukuran tersebut maka tinggi badan korban diperkirakan 150-160 $\mathrm{cm}$. Sebab kematian tidak dapat ditentukan karena jenazah sudah mengalami adiposera.

\section{DAFTAR PUSTAKA}

[1] Amir A. Rangkaian Ilmu Kedokteran Forensik Edisi kedua. Medan: Percetakan Ramadhan; 2009.

[2] Kristanto E. Pemeriksaan Kedokteran Forensik Setelah Ekshumasi di Sulawesi Utara: Kontribusi dan Tantangan. Jurnal Biomedik. 2019;11(3):192-8.

[3] Yaylak D. Case specific autopsy process of corpses pulled out of water. 2014;(1):46-8.

[4] Aflanie I, Nirmalasari N, Arizal MH. Ilmu Kedokteran Forensik dan Medikolegal. Jakarta: Rajawali Press; 2017.

[5] Matuszewski S. Post-mortem interval estimation based on insect evidence: Current challenges. Insects. 2021;12(4):1-21.

[6] Parinduri AG. Identifikasi tulang belulang. Anatomika Medical Journal. 2018; 1 (1): 1-13.

[7] Hamburda OA. Forensic methods of identifying corpses with unknown identity. SSRN Electronic Journal [Internet]. 2019; Available from: https://www.ssrn.com/abstract $=3459667$

[8] Priya E. Methods of skeletal age estimation used by forensic anthropologists in adults: a review. Foresic Research Criminology International Journal. 2017;4(2):41-51.

[9] Alkass K, Buchholz BA, Ohtani S, Yamamoto T, Druid $\mathrm{H}$, Spalding KL. Age estimation in forensic sciences: Application of combined 
aspartic acid racemization and radiocarbon analysis.

Molecular Cellular

Proteomics. 2010;9(5):1022-

30.

[10] Lodha A. Forensic

nanotechnology in forensic genetics. Peer Revew Journal Forensic Genetic Science. 2018;1(2):19-22.

[11] Shukla S, Sharma D, Chauhan A, Kumar N. DNA profiling from drown dead bodies. International Journal Molecular Biology. 2019;4(3):90-4. 